\title{
Education, Occupational Class, and Unemployment in the Regions of the United Kingdom
}

\author{
Vani K. Borooah* \\ University of Ulster
}

January 2007

\begin{abstract}
Estimating the returns to education is an important aspect of empirical economics.

Usually this is achieved by estimating the additional earnings provided by an extra year of schooling. However, given the difficulty of obtaining reliable earnings data, this approach is not always easy to implement. This paper proposes an alternative measure of returns to education based on the probability of "labour market success" associated with different levels of qualification. Returns to education, so conceived, are estimated on data from the 2001 UK Census for the different regions of the UK. Two measures of "success" are used: first, the likelihood of persons in employment being in "good" jobs; second, the likelihood of persons in the labour force being in employment. The results show that, in every region of the UK, better qualifications are significantly and strongly associated with higher probabilities of labour market success.
\end{abstract}

\footnotetext{
* School of Economics and Politics, University of Ulster, Newtownabbey, Northern Ireland BT37 0QB, United Kingdom. E-mail: VK.Borooah@ulster.ac.uk . I am grateful to the Department for Employment and Learning, Northern Ireland for supporting this project and to the Cathy Marsh Centre for Census and Survey Research at the University of Manchester for the use of data from the Sample of Anonymised Records of the 2001 Census for the United Kingdom of Great Britain and Northern Ireland. However, needless to say, I am entirely responsible for the paper and, in particular, for its shortcomings.
} 


\section{Introduction}

Conventional wisdom has it that education is the handmaiden of prosperity. Indeed, one of the most popular textbooks in economics (Mankiw, 1998) asserts that "Education is at least as important as investment in physical capital for a country's long-term success ..... one way in which government policy can enhance the standard of living is to provide good schools and encourage the population to take advantage of them" (p. 528). This theoretical underpinning now forms the raison d'etre of government skills policy; at the national level the Leitch Review is considering what the UK's long-term ambition should be for developing skills in order to maximise economic prosperity and productivity. In Northern Ireland the Department for Learning and Employment in its Skills Strategy seeks to provide an overarching framework for the development of the local skills base. Given the importance of education in determining a person's material well-being, it is natural to enquire about the returns to education. In particular, is it possible to quantify the extent to which a person is made better off through more education?

Economists, beginning with Mincer (1958), have sought to answer this question by estimating the net effect of years of schooling on the earnings of individuals. The recognition that not all the additional earnings of better educated workers can be ascribed to their superior education has led to controls for the noneducational characteristics of individuals being imposed before estimating their returns to education. These controls may relate to age, gender, place of residence, individual ability or motivation. Based on a survey of 97 studies that estimated returns to education, Ashenfelter et. al. (1999) concluded that the return to an additional years schooling was between 6 and 9 percent. 
However, such studies, relating earnings to years of schooling, suffer from two problems. ${ }^{1}$ First, there is a dearth of reliable data on earnings. Second, it is qualifications, rather than years of schooling, which are the passport to higher earnings; acquiring qualifications requires not just spending time in an educational institution but also having something to show for the time spent.

In the face of these problems, we develop an alternative concept of returns to education. In essence, this involves estimating the amount by which the probability of "labour market success" increases with higher educational qualifications. We use two concepts of "labour market success": for persons who are employed, "success" means doing a high, rather than a low, occupational status job; for persons in the labour force, "success" means being employed rather than unemployed.

Data from the 2001 Census for the UK were used to put empirical flesh on this conceptual skeleton. The Sample of Anonymised Records (SARS) of the 2001 Census for the United Kingdom reported the highest qualification for 1,031,840 persons between the ages of 16-74 years. In addition, the SARs inter alia also provided details of a person's non-educational characteristics: gender, region of residence, age, employment status, occupation, ethnicity, place of birth. Using this information we estimated the probabilities of: (i) employed individuals being in jobs of different occupational types; (ii) persons in the labour force being unemployed. This allowed us to estimate, after imposing the appropriate non-educational controls, the link between "doing well" in the labour market and educational qualifications.

\section{Education Qualifications and the 2001 Census for the UK}

\footnotetext{
${ }^{1}$ See Dutta et.al. (1999) and Harmon et.al. (2003) for surveys of the literature on returns to education.
} 
As mentioned earlier, the SARS of the 2001 Census for the United Kingdom reported the highest qualification for $1,031,840$ persons between the ages of 16-74 years. The qualifications were reported as: (i) no qualifications; (ii) Level 1 qualifications (roughly, at least one GCSE); (ii) Level 2 qualifications (roughly, 5+ GCSEs at A-C grades); (iii) Level 3 qualifications (roughly, 2+ 'A' levels); (iv) Level 4 qualifications (first degree or higher, HNC, HND). These qualification levels are detailed in the notes to Table $1 .^{2}$ Table 1 shows the percentage of respondents with these qualifications in the different UK regions. So, for example, of the 30,482 Northern Ireland respondents aged 16-74, 38 percent had "no qualifications" while 18 percent had Level 4 qualifications.

The most striking feature of Table 1 is the marked disparity between the "north" and the "south" of the United Kingdom in the proportion of respondents without any qualifications. Approximately, 30 percent of the respondents in the North East, the North West, the East and West Midlands, Wales, and Scotland had no qualifications compared to around 22 percent for the East, the South East, the South West, and inner and outer London. Of all the regions of the United Kingdom, Northern Ireland had the highest proportion of respondents (38 percent) with no qualifications.

At the other end of the qualifications spectrum, Table 1 shows that 44 percent of respondents in inner London, 31 percent in outer London, and 27 percent in the South East had Level 4 qualifications. At the other extreme, only 18 percent of respondents in Northern Ireland and in the North East had level 4 qualifications. In

\footnotetext{
${ }^{2}$ It should be noted that these were the levels reported at the time that the 2001 Census was undertaken. As from September 2004 there has been a movement towards the National Qualifications Framework (NQF) which comprises nine levels (Entry level to level 8). Whilst entry level and levels 1 to 3 did not change, levels 4 to 5 have been divided into the more precise levels 4 to 8 . While a qualification title might have changed to reflect the more precise levels, the qualification content and demand on the learner has not changed.
} 
the other regions the proportion of respondents with Level 4 qualifications was fairly equal at approximately 21 percent.

Tables 2 and 3 show that when the upper age limit of respondents was reduced to, respectively, 45 and 30 years the proportion of respondents with no qualifications fell dramatically: the proportion of respondents in Northern Ireland without any qualifications fell from 38 percent (Table 1: aged 16-74) to 24 percent (Table 2: aged 16-45 years), to 12.9 percent (Table 3: aged 16-30 years). At the other extreme, reducing the upper age limit also increased the proportion of respondents with Level 4 qualifications though, compared to proportions with no qualifications, the results were much more muted: for example, the proportion of respondents in Northern Ireland with Level 4 qualifications rose from 18 percent (Table 1: aged 16-74) to 20.4 percent (Table 2: aged 16-45 years), to 21.3 percent (Table 3: aged 16-30 years).

Table 4 shows for, Northern Ireland, differences between the proportions of Catholics and Protestants with different qualifications: the associated t values provide a test of whether these inter-community differences were significantly different from zero. While there was no significant difference between the proportions of Catholics and Protestant respondents, taken in their entirety (i.e. 16-74), without any qualifications, the proportion of Catholic respondents without any qualifications was significantly higher than that for Protestants for the truncated age groups, 16-45 and 16-30 years. However, at the other end of the qualifications spectrum, the proportion of Catholic respondents with Level 4 qualifications was significantly higher than that for Protestants for all the age groups: 16-74, 16-45, and 16-30 years. Compared to Protestants, Catholics were more likely to be without qualifications but also more likely to have the highest level of qualifications. 
It is important that the data in Table 4 is set within the context of Higher Education migration in Northern Ireland. The empirical evidence tends to suggest that a higher proportion of Protestants migrate to Great Britain (GB) for HE purposes with a significant proportion not returning. This seems a strong explanatory factor in explaining the finding that Catholics have the highest levels of qualification.

Table 7 shows the relationship between qualifications and occupational class. For example, in Northern Ireland, only 11.9 percent of respondents without any qualifications, compared to 73 percent of respondents with Level 4 qualifications, were in managerial, professional or technical (PMT) occupations; on the other hand, 25 percent of those without any qualifications, compared to only 2.5 percent of those with Level 4 qualifications, were in elementary occupations. Table 7 also shows that the proportion of persons with Level 4 qualifications in PMT occupations in all the other regions of the United Kingdom (approximately, 77 percent) was (statistically) significantly higher than in Northern Ireland (73 percent): compared to other UK regions, persons with Level 4 qualifications in Northern Ireland were underrepresented in PMT occupations and over-represented in skilled manual/non-manual occupations.

Table 8 shows the relationship between qualifications and two states of economic status: unemployment and being permanently sick or disabled (PSD). In Northern Ireland, 49.5 percent of unemployed persons (seeking work and available to start within 2 weeks) and 75.1 percent of the PSD had no qualifications; conversely, only 9.6 percent of those unemployed and only 4.5 percent of the PSD, in Northern Ireland, had Level 4 qualifications. In this respect, Northern Ireland's experience contrasts with that of the other UK regions where persons with Level 4 qualifications were proportionately more strongly represented among the unemployed and the PSD: 
for example, in inner London, the proportion of the unemployed who had no qualifications was, at 26 percent, the same as the proportion of the unemployed who had Level 4 qualifications.

Table 9 shows unemployment rates (the proportion of respondents in the labour force seeking work and available to start within 2 weeks) and the sickness/disability rates (proportion of the non-student, non-retired population which is permanently sick or disabled) by highest level of qualification. This Table shows that, in every UK region, better qualifications were associated with lower unemployment and disability rates. The unemployment rate for unqualified persons was significantly above the regional average and the unemployment rate for those with Level 4 qualifications was significantly below. For example, in the context of an overall unemployment rate of 6.7 percent in Northern Ireland, the unemployment rate in that region, for respondents without any qualifications, was 11.5 percent compared to a rate of 2.9 percent for persons with Level 4 qualifications.

\section{Comparing LFS and Census data}

There is a rather large discrepancy between the Labour Force Survey (LFS) and the Census in relation to skills reporting. Undoubtedly the Census of Population offers the most accurate recent baseline for numbers of people with each skill. However, the fact remains that Census figures show a significantly different distribution of skills from the LFS. For example, in the Census a lower proportion of people have level $4 / 5$ skills (15.8\% compared with $18.5 \%$ in the LFS in 2001). A much higher proportion have level 1 or o skills (58\% compared with $36.5 \%$ in the LFS). The largest difference of all is in Level 3 skills, held by only $9 \%$ of workingage people in the census compared with $23 \%$ in the LFS for 2001 . These differences 
are large and are not due to sampling fluctuations. The Northern Ireland Statistical Research agency (NISRA) is currently investigating the reasons behind the differences: they have suggested that it may be due to the fact that respondents to the LFS are interviewed by an experienced interviewer, qualifications are more correctly assigned to the relevant skills level. On the other hand respondents to the Census are completing the forms by themselves and therefore they may incorrectly categorise their qualifications. It should be emphasised that this Report is entirely Census based and does not, therefore, seek to make any such comparisons.

\section{Econometric Methodology: Ordered Logit}

Suppose there are $N$ persons (indexed $i=1 \ldots N$ ). Let the values taken by the variable $Y_{i}$ represent the occupational status of these persons such that: $Y_{i}=1$ if the person was employed in a PMT occupation; $Y_{i}=2$ if the person was employed in a skilled manual or non-manual occupation; and $Y_{i}=3$ if the person was an elementary worker. Since these outcomes are inherently ordered - in the sense that the outcome associated with a higher value of $Y_{i}$ is of lower "occupational status" than that associated with a lower value - the appropriate method of estimation is that of ordered logit.

The idea behind this model (Borooah, 2001) is that the occupational status of a person may be represented by the value of the latent variable, $H_{i}$, with higher values of $H_{i}$ representing lower status. One may consider this latent variable to be a linear function of $K$ "status-determining" factors whose values for individual $i$ are: $X_{i k}, k=1 \ldots K$. Consequently, 


$$
H_{i}=\sum_{k=1}^{K} X_{i k} \beta_{k}+\varepsilon_{i}=Z_{i}+\varepsilon_{i}
$$

where: $\beta_{k}$ is the coefficient associated with the $k^{\text {th }}$ variable and $Z_{i}=\sum_{k} X_{i k} \beta_{k}$. An increase in the value of the $k^{\text {th }}$ factor will cause the status of a person to improve if $\beta_{k}<0$ and to deteriorate if $\beta_{k}>0$.

Since the values of $H_{i}$ are, in principle and in practice, unobservable, equation (1) represents a latent regression which, as it stands, cannot be estimated. However, what is observable is a person's occupational status and the categorisation of persons in the sample in terms of occupational status is implicitly based on the values of the latent variable $H_{i}$ in conjunction with 'threshold values', $\delta_{1}$ and $\delta_{2}$ $\left(\delta_{1}<\delta_{2}\right)$ such that:

$$
\begin{aligned}
& Y_{i}=1, \text { if } H_{i} \leq \delta_{1} \\
& Y_{i}=2, \text { if } \delta_{1}<H_{i} \leq \delta_{2} \\
& Y_{i}=3, \text { if } H_{i}>\delta_{2}
\end{aligned}
$$

The $\delta_{1}, \delta_{2}$ of equation (2) are unknown parameters to be estimated along with the $\beta_{k}$ of equation (1).

A person's classification in terms of his/her occupational status depends upon whether the value of $H_{i}$ crosses a threshold and the probabilities of a person being in a particular occupational status are:

$$
\begin{aligned}
& \operatorname{Pr}\left(Y_{i}=1\right)=\operatorname{Pr}\left(\varepsilon_{i} \leq \delta_{1}-Z_{i}\right) \\
& \operatorname{Pr}\left(Y_{i}=2\right)=\operatorname{Pr}\left(\delta_{1}-Z_{i} \leq \varepsilon_{i}<\delta_{2}-Z_{i}\right) \\
& \operatorname{Pr}\left(Y_{i}=3\right)=\operatorname{Pr}\left(\varepsilon_{i} \geq \delta_{2}-Z_{i}\right)
\end{aligned}
$$

If it is assumed that the error term $\varepsilon_{i}$, in equation (1), follows a logistic distribution then equations (1) and (2) collectively constitute an ordered logit model ${ }^{3}$

\footnotetext{
${ }^{3}$ The assumption that the $\varepsilon_{\mathrm{i}}$ are normally distributed results in an ordered probit model.
} 
and the estimates from this model permit, through equation (3), the various probabilities to be computed for every person in the sample, conditional upon the values of the status-determining factors for that person.

The ordered logit estimates for estimating equations (1) and (2), with $Y_{i}$ as the dependent variable (defined above), are shown in Table 10 for each of seven broad areas of the UK: the North, North West and Yorkshire; the East and West Midlands; the East, South East and South West; inner and outer London; Wales; Scotland; and Northern Ireland. The equation was estimated on data for all persons who were in employment, either as employees or as self-employed. The estimated parameters $\hat{\beta}_{k}$, $\hat{\delta}_{1}$ and $\hat{\delta}_{2}$ maximise the likelihood of observing the values of the dependent variables, conditional upon the values assumed by the determining variables. The z-ratios, shown parenthetically in Table 10, are the ratios of the estimated coefficients to their estimated standard errors: the z-ratios are (asymptotically) distributed as $N(0,1)$ under the null hypothesis that the associated coefficients are zero.

\section{Estimation Results: Marginal Probabilities of Occupational Status}

A natural question to ask from the ordered logit model is how the probabilities of being in the different categories of occupational status changed in response to a change in the value of one of the status-affecting factors, the values of the other factors remaining unchanged. Unfortunately, the coefficient estimates themselves do not provide a clear answer to this question. If $\beta_{k}<0$, then, in response to an increase in the value of the $k^{\text {th }}$ determining factor, $\operatorname{Pr}\left(Y_{i}=1\right)$ will rise and $\operatorname{Pr}\left(Y_{i}=3\right)$ will fall. However, since the change in probabilities across all three outcomes must sum to zero, it is not clear what would happen to the middle probability, $\operatorname{Pr}\left(Y_{i}=2\right)$ : it may rise or fall. Given a change in the value of a determining variable, it is impossible, 
therefore, to infer, from the sign of its coefficient estimate, the direction of change in all the probabilities. For this reason Greene (2000) cautions that "we must be very careful in interpreting the coefficients in this model...since it is the least obvious of the [discrete choice] models" (p. 878).

For this reason, the estimation results are discussed in terms of "marginal probabilities". The marginal probability, associated with a determining variable, of being employed in a particular occupation, is the change in the probability of employment in that occupation consequent upon an unit change in the determining variable, the values of the other variables remaining unchanged. For discrete variables, the marginal probabilities refer to changes consequent upon a move from the residual category for that variable to the category in question.

Table 11 shows the marginal probability of being employed in a PMT job associated with a unit change in each of the determining variables. For example, Table 11 shows that in Northern Ireland a change in qualifications from "no qualifications" to Level 1 qualifications increases the probability of employment in a PMT job by 18.3 points; a change in qualifications from "no qualifications" to Level 4 qualifications increases the probability of employment in a PMT job by 68.2 points; and, by corollary, a change in qualifications from Level 3 to Level 4 qualifications increases the probability of employment in a PMT job by 30.3 (68.2-37.9) points.

Table 11 shows that, for employed persons, the probability of PMT employment rises with higher qualifications: across the UK regions, the marginal probabilities of being in PMT employment, for Level 4 qualifications, were between approximately 66 (lowest)-70 (highest); the corresponding ranges for the PMT marginal probabilities for Level 3, Level 2, and Level 1 qualifications were, respectively, 36-45, 30-36, and 18-24 points. 
An important feature of Table 11 is that in every UK region, the marginal probability of women being in PMT employment was negative: ceteris paribus women, compared to male, employees were less likely to be in PMT employment. Table 11 also shows that the marginal probability of being in PMT employment rose with age, reached a maximum at 45-54 years, and then fell. Asian and Black employees in the Midlands, the South, and in London were less likely to be in PMT employment ceteris paribus than Whites; however, there did not appear to be an "ethnic effect" (except a negative effect for Blacks in the North, North West, and Yorkshire) associated with PMT employment in the other UK regions. It should be noted that issues of ethnicity were not relevant for Northern Ireland where the sample was, almost exclusively, White.

\section{Estimation Results: Marginal Probabilities of Unemployment}

The preceding section addressed the question of the occupational status of persons who were employed. A related question of interest is how the probability of a person, who was in the labour force, being unemployed was influenced by his/her personal characteristics and circumstances. In order to answer this question we estimated a logit model in which the dependent variable $Y_{i}=1$ if person $i$ was unemployed and $Y_{i}=0$ if person $i$ was employed (employee or self-employed). ${ }^{4}$ The results of estimating this equation for the different regions of the UK are shown in Table 12. A positive (negative) coefficient estimate indicates that the probability of being unemployed rises (falls) with an increase in the value of the variable associated with the coefficient. However, the coefficient estimates do not provide a guide to the

\footnotetext{
${ }^{4}$ The logit equation is $\frac{\operatorname{Pr}\left(Y_{i}=1\right)}{1-\operatorname{Pr}\left(Y_{i}=1\right)}=\exp \left\{\sum_{k=1}^{K} X_{i k} \beta_{i}\right\}=\exp \left\{z_{i}\right\}$ for K coefficients, $\beta_{\mathrm{i}}$ and for observations on $\mathrm{K}$ variables where $\operatorname{Pr}\left(Y_{i}=1\right)=e^{z} /\left(1+e^{z}\right)$
} 
amount by which the probability of unemployment increases or decreases in consequence of a change in the variable value.

These marginal probabilities are shown in Table $13 .{ }^{5}$ In the present context, the marginal probability, associated with a determining variable, of being unemployed is the change in the probability of unemployment consequent upon an unit change in the determining variable, the values of the other variables remaining unchanged. For discrete variables, the marginal probabilities refer to changes consequent upon a move from the residual category for that variable to the category in question.

Table 13 shows that, for persons in the labour force, the marginal probability of unemployment falls with higher qualifications: across the UK regions, the marginal probabilities of being unemployed, for Level 4 qualifications, were between -2.6 (lowest) to -6.7 (highest). The equation predicted that, after controlling for noneducational factors, the probability of an unqualified person in Northern Ireland being unemployed was 10.5 percent. So, for example, compared to an unqualified person in the Northern Ireland labour force being unemployed, the probabilities of persons with Level 4, Level 3, Level 2, and Level 1 qualifications being unemployed were, respectively, $6.2,4.6,4.1$, and 3.3 percentage points lower than 10.5 percent.

The probability of being unemployed also varied by age. Compared to the youngest age group, 19-29 years, the marginal probability of unemployment for the other age groups was always negative, indicating that they were less likely to be unemployed - being most negative for persons in the labour force between 45-54 years. Table 13 also shows that, except in Wales, there was a significant ethnic dimension to unemployment: compared to White persons, the probability of being

\footnotetext{
${ }^{5}$ The marginal probability is defined as $\frac{\partial \operatorname{Pr}\left(Y_{i}=1\right)}{\partial X_{i k}}$
} 
unemployed was higher for Asians, Chinese, and Blacks. In Northern Ireland, the probability of a Catholic being unemployed was 3.3 points higher than for Protestants. Lastly, in every region of the UK, the probability of women in the labour force being unemployed was always lower than that for men.

\section{Conclusions}

Estimating the returns to education is an important aspect of empirical economics. Usually this is achieved by estimating the additional earnings provided by an extra year of schooling. However, as noted earlier, given the difficulty of obtaining reliable earnings data, this approach is not always easy to implement. This paper proposed an alternative measure of returns to education based on the probability of "labour market success" associated with different levels of qualification. Returns to education, so conceived, were estimated on data from the 2001 UK Census for the different regions of the UK. Two measures of "success" were used: first, the likelihood of persons in employment being in "good" jobs; second, the likelihood of persons in the labour force being in employment. The results showed that, in every region of the UK, better qualifications were significantly, and strongly, associated with higher probabilities of labour market success.

Against this general conclusion, we may distinguish different patterns of interregional details.

1. There is the marked disparity between the "north" and the "south" of the United Kingdom in the proportion of respondents without any qualifications. Approximately, 30 percent of the respondents in the North East, the North West, the East and West Midlands, Wales, and Scotland had no qualifications compared to around 22 percent for the East, the 
South East, the South West, and inner and outer London. Of all the regions of the United Kingdom, Northern Ireland had the highest proportion of respondents ( 38 percent) with no qualifications. At the other end of the qualifications spectrum, Table 1 shows that 44 percent of respondents in inner London, 31 percent in outer London, and 27 percent in the South East had Level 4 qualifications. At the other extreme, only 18 percent of respondents in Northern Ireland and in the North East had level 4 qualifications. In the other regions the proportion of respondents with Level 4 qualifications was fairly equal at approximately 21 percent.

2. The proportion of persons with Level 4 qualifications in PMT occupations in all the other regions of the United Kingdom (approximately, 77 percent) was (statistically) significantly higher than in Northern Ireland (73 percent): compared to other UK regions, persons with Level 4 qualifications in Northern Ireland were under-represented in PMT occupations and over-represented in skilled manual/non-manual occupations.

3. In Northern Ireland, 49.5 percent of unemployed persons (seeking work and available to start within 2 weeks) and 75.1 percent of the PSD had no qualifications; conversely, only 9.6 percent of those unemployed and only 4.5 percent of the PSD, in Northern Ireland, had Level 4 qualifications. In this respect, Northern Ireland's experience contrasts with that of the other UK regions where persons with Level 4 qualifications were proportionately more strongly represented among the unemployed and the PSD: for example, in inner London, the proportion of the unemployed who 
had no qualifications was, at 26 percent, the same as the proportion of the unemployed who had Level 4 qualifications.

4. In every UK region, better qualifications were associated with lower unemployment rates and low disability rates. The unemployment rate and the disability rate for unqualified persons was significantly above the regional average and the unemployment rate for those with Level 4 qualifications was significantly below. For example, in the context of an overall unemployment rate of 6.7 percent in Northern Ireland, the unemployment rate in that region, for respondents without any qualifications, was 11.5 percent compared to a rate of 2.9 percent for persons with Level 4 qualifications.

5. Ceteris paribus the probability of PMT employment rose with higher qualifications: across the UK regions, the marginal probabilities of being in PMT employment, for Level 4 qualifications, were between approximately 66 (lowest)-70 (highest); the corresponding ranges for the PMT marginal probabilities for Level 3, Level 2, and Level 1 qualifications were, respectively, 36-45, 30-36, and 18-24 points.

6. The marginal probability of women being in PMT employment was negative: ceteris paribus women, compared to male, employees were less likely to be in PMT employment. The marginal probability of being in PMT employment rose with age, reached a maximum at 45-54 years, and then fell.

7. For persons in the labour force, the marginal probability of unemployment falls with higher qualifications: across the UK regions, the marginal probabilities of being unemployed, for Level 4 qualifications, were 
between -2.6 (lowest) to -6.7 (highest). The equation predicted that, after controlling for non-educational factors, the probability of an unqualified person in Northern Ireland being unemployed was 10.5 percent. So, for example, compared to an unqualified person in the Northern Ireland labour force being unemployed, the probabilities of persons with Level 4, Level 3, Level 2, and Level 1 qualifications being unemployed were, respectively, $6.2,4.6,4.1$, and 3.3 percentage points lower than 10.5 percent.

8. The probability of being unemployed also varied by age. Compared to the youngest age group, 19-29 years, the marginal probability of unemployment for the other age groups was always negative, indicating that they were less likely to be unemployed - being most negative for persons in the labour force between 45-54 years. 


\section{References}

Ashenfelter, O., Harmon, C., and Oosterbeek, H. (1999), A Review of

Estimates of the Schooling/Earnings Relationship, with Tests for Publication Bias.”

Labour Economics, Vol. 6, pp. 453-470.

Borooah, V.K. (2001), Logit and Probit: Ordered and Multinomial Models, Quantitative Studies in the Social Sciences, Thousand Oaks, CA: Sage Publications Inc.

Dutta, J., Sefton, J., and Weale, M. (1999), "Education and Public Policy," Fiscal Studies, vol. 20, pp. 351-386.

Harmon, C., Oosterbeek, H. and Walker, I. (2003) “The Returns to Education - A Review of Evidence, Issues and Deficiencies in the Literature." (with). Journal of Economic Surveys, vol. 17, pp. 155-156.

Hornbeck, D.W., and Salamon, L.M. (1991), Human Capital and America's

Future, Batlimore: The Johns Hopkins Press.

Greene, W.H., (2000), Econometric Analysis, Englewood Cliffs: Prentice Hall.

Mankiw, N.G. (1998), Principles of Economics, New York: Worth Publishers Inc.

Mincer, J. (1958), “Investment in Human Capital and Personal Income

Distribution", Journal of Political Economy, vol. 66, pp. 281-302.

Prais, S.J. (1995), Productivity, Education and Training, London: National Institute of Economic and Social Research. 
Table 1

Level of Highest Qualifications by UK Region, 2001, aged 16-74

\begin{tabular}{|c|c|c|c|c|c|}
\hline & \multicolumn{5}{|c|}{ Percentage of Respondents, aged 16-74, with relevant qualification } \\
\hline & $\begin{array}{c}\text { No } \\
\text { Qualifications }\end{array}$ & Level 1 & Level 2 & Level 3 & Level 4 \\
\hline $\begin{array}{l}\text { North East } \\
(43,202)\end{array}$ & 31.7 & 20.9 & 20.6 & 8.9 & 17.9 \\
\hline $\begin{array}{l}\text { North West } \\
(114,879)\end{array}$ & 29.5 & 20.1 & 20.7 & 9.4 & 20.3 \\
\hline $\begin{array}{l}\text { Yorkshire } \\
(84,138)\end{array}$ & 30.8 & 20.7 & 19.2 & 9.5 & 19.8 \\
\hline $\begin{array}{l}\text { East } \\
\text { Midland } \\
(71,878)\end{array}$ & 29.2 & 21.1 & 20.0 & 9.4 & 20.3 \\
\hline $\begin{array}{l}\text { West } \\
\text { Midland } \\
(89,649)\end{array}$ & 31.7 & 20.1 & 20.1 & 8.8 & 19.4 \\
\hline $\begin{array}{l}\text { East } \\
(92,521)\end{array}$ & 24.8 & 22.0 & 22.0 & 9.4 & 21.8 \\
\hline $\begin{array}{l}\text { South East } \\
(138,810)\end{array}$ & 20.9 & 20.1 & 22.5 & 10.9 & 26.7 \\
\hline $\begin{array}{l}\text { South West } \\
(83,081)\end{array}$ & 23.0 & 21.5 & 23.1 & 10.3 & 22.2 \\
\hline $\begin{array}{l}\text { Inner } \\
\text { London } \\
(54,751)\end{array}$ & 20.3 & 10.4 & 13.9 & 11.2 & 44.3 \\
\hline $\begin{array}{l}\text { Outer } \\
\text { London } \\
(79,533)\end{array}$ & 21.4 & 17.1 & 20.0 & 10.8 & 30.9 \\
\hline $\begin{array}{l}\text { Wales } \\
(49,118)\end{array}$ & 30.5 & 18.3 & 21.6 & 8.9 & 20.7 \\
\hline $\begin{array}{l}\text { Scotland } \\
(99,798)\end{array}$ & 29.5 & 24.9 & 16.1 & 8.1 & 21.4 \\
\hline $\begin{array}{l}\text { Northern } \\
\text { Ireland } \\
(30,482)\end{array}$ & 38.0 & 18.3 & 15.7 & 10.0 & 18.0 \\
\hline $\begin{array}{l}\text { England, } \\
\text { Wales, and } \\
\text { Northern } \\
\text { Ireland } \\
(932,042) \\
\end{array}$ & 26.7 & 19.6 & 20.5 & 9.8 & 23.4 \\
\hline
\end{tabular}

Source: 2001 UK Census, Sample of Anonymised Records 


\section{Notes to Table 1}

Figures in parentheses are numbers in sampled in region

Education levels are defined as follows:

England and Wales:

Level 1: 1+ 'O' level passes, 1+ CSE/GCSE any grades, NVQ level 1, Foundation GNVQ

Level 2: 5+ 'O' level passes, 5+ CSE (grade 1), 5+ GCSE (A-C grades), School

Certificate, 1+ 'A' levels/AS levels, NVQ level 2, Intermediate GNVQ

Level 3: 2+ 'A' levels, 4+ AS levels, Higher School Certificate, NVQ level3, Advanced GVNQ

Level 4: First degree, Higher degree, NVQ levels 4 and 5, HNC, HND, Qualified Teacher status, Qualified Medical Doctor/Dentist/Nurse/Midwife/Health Visitor Scotland:

Level 1: 'O' grade, Standard Grade, Intermediate 1, Intermediate 2, City and Guilds Craft, SVQ level 1 or 2 or equivalent

Level 2: Higher Grade, CSYS, ONC, OND, City and Guilds Advanced Craft, RSA, Advanced Diploma, SVQ level 3 or equivalent

Level 3: HND, HNC, RSA Higher Diploma, SVQ level 4 or 5 or equivalent

Level 4: First degree, Higher degree, Professional qualification

Northern Ireland:

Level 1: GSCE (grades D-G), CSE (grades 2-5), 1-4 CSEs (grade 1), 1-4 GCSES (grades A-C), 1-4 'O' level passes, NVQ level 1, Foundation GNVQ or equivalents Level 2: 5+ 'O' level passes, 5+ CSE (grade 1), 5+ GCSE (A-C grades), Senior Certificate, 1 'A' levels, 1-3 AS levels, Advanced Senior Certificate, NVQ level 2, Intermediate GNVQ or equivalents

Level 3: 2+ 'A' levels, 4+ AS levels, NVQ level 3, GNVQ Advanced or equivalents Level 4: First degree, Higher degree, NVQ levels 4 and 5, HNC, HND

In England and Wales, the highest level of qualification was derived from responses to both the qualifications qualification and the professional qualifications question; in Scotland and Northern Ireland, it was based only on the qualifications question.

Source: 2001 UK Census, Sample of Anonymised Records 
Table 2

Level of Highest Qualifications by UK Region, 2001, aged 16-45

\begin{tabular}{|c|c|c|c|c|c|}
\hline & \multicolumn{5}{|c|}{ Percentage of Respondents, aged 16-45, with relevant qualification } \\
\hline & $\begin{array}{c}\text { No } \\
\text { Qualifications }\end{array}$ & Level 1 & Level 2 & Level 3 & Level 4 \\
\hline $\begin{array}{l}\text { North East } \\
(26,752)\end{array}$ & 18.4 & 25.9 & 25.4 & 11.9 & 18.3 \\
\hline $\begin{array}{l}\text { North West } \\
(70,769)\end{array}$ & 16.9 & 23.8 & 25.3 & 12.6 & 21.5 \\
\hline $\begin{array}{l}\text { Yorkshire } \\
(52,406)\end{array}$ & 19.2 & 25.0 & 23.0 & 12.7 & 20.2 \\
\hline $\begin{array}{l}\text { East } \\
\text { Midland } \\
(44,051)\end{array}$ & 16.5 & 25.6 & 24.1 & 12.6 & 21.2 \\
\hline $\begin{array}{l}\text { West } \\
\text { Midland } \\
(55,004)\end{array}$ & 19.4 & 24.3 & 24.0 & 11.8 & 20.5 \\
\hline $\begin{array}{l}\text { East } \\
(56,697)\end{array}$ & 13.4 & 26.0 & 25.9 & 12.1 & 22.7 \\
\hline $\begin{array}{l}\text { South East } \\
(85,647)\end{array}$ & 11.1 & 22.8 & 25.5 & 13.6 & 27.0 \\
\hline $\begin{array}{l}\text { South West } \\
(49,395)\end{array}$ & 12.0 & 25.6 & 26.7 & 13.4 & 22.2 \\
\hline $\begin{array}{l}\text { Inner } \\
\text { London } \\
(40,882)\end{array}$ & 13.3 & 10.8 & 14.5 & 12.5 & 48.9 \\
\hline $\begin{array}{l}\text { Outer } \\
\text { London } \\
(52,955)\end{array}$ & 12.7 & 18.5 & 22.01 & 12.9 & 34.0 \\
\hline $\begin{array}{l}\text { Wales } \\
(29,073)\end{array}$ & 19.3 & 22.2 & 25.1 & 12.0 & 21.4 \\
\hline $\begin{array}{l}\text { Scotland } \\
(59,761)\end{array}$ & 18.1 & 29.6 & 19.9 & 10.3 & 22.1 \\
\hline $\begin{array}{l}\text { Northern } \\
\text { Ireland } \\
(19,269)\end{array}$ & 24.2 & 23.5 & 18.4 & 13.5 & 20.4 \\
\hline $\begin{array}{l}\text { England, } \\
\text { Wales, and } \\
\text { Northern } \\
\text { Ireland } \\
(582,900) \\
\end{array}$ & 15.5 & 22.9 & 23.8 & 12.7 & 25.1 \\
\hline
\end{tabular}

See Notes to Table 1

Source: 2001 UK Census, Sample of Anonymised Records 
Table 3

Level of Highest Qualifications by UK Region, 2001, aged 16-30

\begin{tabular}{|c|c|c|c|c|c|}
\hline & \multicolumn{5}{|c|}{ Percentage of Respondents, aged 16-30, with relevant qualification } \\
\hline & $\begin{array}{c}\text { No } \\
\text { Qualifications }\end{array}$ & Level 1 & Level 2 & Level 3 & Level 4 \\
\hline $\begin{array}{l}\text { North East } \\
(9,943)\end{array}$ & 13.3 & 19.0 & 26.9 & 22.3 & 18.5 \\
\hline $\begin{array}{l}\text { North West } \\
(26,950)\end{array}$ & 13.0 & 18.1 & 26.9 & 21.6 & 20.4 \\
\hline $\begin{array}{l}\text { Yorkshire } \\
(20,315)\end{array}$ & 14.5 & 19.4 & 24.3 & 22.6 & 19.2 \\
\hline $\begin{array}{l}\text { East } \\
\text { Midland } \\
(16,477)\end{array}$ & 12.4 & 18.7 & 25.8 & 22.5 & 20.6 \\
\hline $\begin{array}{l}\text { West } \\
\text { Midland } \\
(21,122)\end{array}$ & 15.3 & 19.3 & 25.0 & 20.2 & 20.3 \\
\hline $\begin{array}{l}\text { East } \\
(21,028)\end{array}$ & 10.3 & 20.1 & 28.1 & 19.4 & 22.2 \\
\hline $\begin{array}{l}\text { South East } \\
(31,650)\end{array}$ & 8.6 & 16.5 & 26.8 & 22.3 & 25.8 \\
\hline $\begin{array}{l}\text { South West } \\
(18,271)\end{array}$ & 8.8 & 19.1 & 28.5 & 22.8 & 20.7 \\
\hline $\begin{array}{l}\text { Inner } \\
\text { London } \\
(18,355)\end{array}$ & 8.9 & 8.5 & 14.1 & 17.8 & 50.7 \\
\hline $\begin{array}{l}\text { Outer } \\
\text { London } \\
(20,819)\end{array}$ & 8.9 & 13.7 & 22.7 & 19.6 & 35.1 \\
\hline $\begin{array}{l}\text { Wales } \\
(11,237)\end{array}$ & 14.1 & 17.7 & 25.8 & 22.0 & 20.5 \\
\hline $\begin{array}{l}\text { Scotland } \\
(22,424)\end{array}$ & 10.9 & 29.7 & 27.2 & 12.2 & 20.0 \\
\hline $\begin{array}{l}\text { Northern } \\
\text { Ireland } \\
(7,395)\end{array}$ & 12.9 & 22.5 & 20.7 & 22.7 & 21.3 \\
\hline $\begin{array}{l}\text { England, } \\
\text { Wales, and } \\
\text { Northern } \\
\text { Ireland } \\
(223,562) \\
\end{array}$ & 11.4 & 17.4 & 24.9 & 21.2 & 25.1 \\
\hline
\end{tabular}

See Notes to Table 1

Source: 2001 UK Census, Sample of Anonymised Records 


\section{Table 4}

Level of Highest Qualifications in Northern Ireland by Religion ${ }^{*}, 2001$

\begin{tabular}{|l|c|c|c|c|c|}
\hline & \multicolumn{5}{|c|}{ Percentage of Respondents, aged 16-74, with relevant qualification } \\
\hline & $\begin{array}{l}\text { No } \\
\text { Qualifications }\end{array}$ & Level 1 & Level 2 & Level 3 & Level 4 \\
\hline $\begin{array}{l}\text { Catholic } \\
(12,015)\end{array}$ & 39.1 & 17.8 & 15.0 & 10.3 & 17.9 \\
\hline $\begin{array}{l}\text { Protestant } \\
(13,845)\end{array}$ & 39.6 & 18.4 & 16.2 & 9.3 & 16.5 \\
\hline $\mathrm{t}$ value & 0.87 & 1.29 & 2.87 & 2.65 & 3.10 \\
\hline & Percentage of Respondents, aged 16-45, with relevant qualification \\
\hline $\begin{array}{l}\text { Catholic } \\
(7,986)\end{array}$ & 26.0 & 22.3 & 17.5 & 13.7 & 20.5 \\
\hline $\begin{array}{l}\text { Protestant } \\
(8,077)\end{array}$ & 23.5 & 24.7 & 19.4 & 13.3 & 19.0 \\
\hline $\mathrm{t}$ value & 3.61 & 3.62 & 3.08 & 0.67 & 2.36 \\
\hline & Percentage of Respondents, aged 16-30, with relevant qualification \\
\hline $\begin{array}{l}\text { Catholic } \\
(3,205)\end{array}$ & 13.9 & 21.3 & 19.3 & 23.4 & 22.2 \\
\hline $\begin{array}{l}\text { Protestant } \\
(2,920)\end{array}$ & 11.5 & 23.4 & 22.0 & 22.8 & 20.3 \\
\hline $\mathrm{t}$ value & 2.78 & 2.0 & 2.64 & 0.55 & 1.82 \\
\hline
\end{tabular}

* Only Catholics and Protestants (Presbyterian, Church of Ireland, Methodist, Other Christian). Persons of other religions, no religion, and not stated religion were excluded.

See Notes to Table 1.

The $t$ values result from testing the null hypothesis of there being no difference between the Catholic and Protestant mean proportions at the relevant qualification. Source: 2001 UK Census, Sample of Anonymised Records 
Table 5

Level of Highest Qualifications in England and Wales by Ethnicity, 2001

\begin{tabular}{|c|c|c|c|c|c|}
\hline & \multicolumn{5}{|c|}{ Percentage of Respondents, aged 16-74, with relevant qualification } \\
\hline & $\begin{array}{c}\text { No } \\
\text { Qualifications }\end{array}$ & Level 1 & Level 2 & Level 3 & Level 4 \\
\hline $\begin{array}{l}\text { White } \\
(822,750)\end{array}$ & 26.3 & 20.2 & 21.1 & 9.7 & 22.8 \\
\hline $\begin{array}{l}\text { Mixed } \\
(7,859)\end{array}$ & 16.3 & 16.1 & 20.0 & 15.1 & 32.5 \\
\hline $\begin{array}{l}\text { Asian } \\
(40,720)\end{array}$ & 33.1 & 12.6 & 14.2 & 10.9 & 29.2 \\
\hline $\begin{array}{l}\text { Black } \\
(20,917)\end{array}$ & 18.1 & 17.8 & 20.7 & 10.3 & 33.2 \\
\hline $\begin{array}{l}\text { Chinese } \\
(9,314)\end{array}$ & 24.1 & 6.5 & 10.1 & 13.2 & 46.1 \\
\hline & \multicolumn{5}{|c|}{ Percentage of Respondents, aged 16-45, with relevant qualification } \\
\hline $\begin{array}{l}\text { White } \\
(504,189)\end{array}$ & 14.6 & 23.8 & 24.7 & 12.6 & 24.3 \\
\hline $\begin{array}{l}\text { Mixed } \\
(6,849)\end{array}$ & 14.3 & 16.7 & 20.5 & 16.1 & 32.3 \\
\hline $\begin{array}{l}\text { Asian } \\
(29,726)\end{array}$ & 26.5 & 14.0 & 15.5 & 13.3 & 30.8 \\
\hline $\begin{array}{l}\text { Black } \\
(16,085)\end{array}$ & 12.5 & 19.6 & 23.1 & 11.8 & 33.0 \\
\hline $\begin{array}{l}\text { Chinese } \\
(6,782)\end{array}$ & 18.7 & 6.2 & 10.2 & 15.6 & 49.3 \\
\hline & \multicolumn{5}{|c|}{ Percentage of Respondents, aged 16-30, with relevant qualification } \\
\hline $\begin{array}{l}\text { White } \\
(189,639)\end{array}$ & 10.8 & 17.8 & 25.9 & 21.2 & 24.3 \\
\hline $\begin{array}{l}\text { Mixed } \\
(3,435) \\
\end{array}$ & 11.3 & 14.1 & 23.2 & 23.4 & 28.0 \\
\hline $\begin{array}{l}\text { Asian } \\
(14,554)\end{array}$ & 19.2 & 13.1 & 17.0 & 20.3 & 30.4 \\
\hline $\begin{array}{l}\text { Black } \\
(5,367)\end{array}$ & 10.3 & 15.6 & 26.9 & 20.1 & 27.1 \\
\hline $\begin{array}{l}\text { Chinese } \\
(3,172)\end{array}$ & 11.6 & 5.6 & 11.9 & 25.3 & 45.7 \\
\hline
\end{tabular}

See Notes to Table 1

Source: 2001 UK Census, Sample of Anonymised Records 
Table 6

Level of Highest Qualifications in Scotland by Ethnicity, 2001

\begin{tabular}{|c|c|c|c|c|c|}
\hline & \multicolumn{5}{|c|}{ Percentage of Respondents, aged 16-74, with relevant qualification } \\
\hline & $\begin{array}{c}\text { No } \\
\text { Qualifications }\end{array}$ & Level 1 & Level 2 & Level 3 & Level 4 \\
\hline $\begin{array}{l}\text { White } \\
(97,849)\end{array}$ & 29.4 & 25.2 & 16.1 & 8.1 & 21.2 \\
\hline $\begin{array}{l}\text { Indian } \\
(351)\end{array}$ & 37.6 & 9.4 & 13.4 & 7.1 & 32.5 \\
\hline $\begin{array}{l}\text { Pakistani } \\
(1,108)\end{array}$ & 35.2 & 15.0 & 15.1 & 7.0 & 27.7 \\
\hline $\begin{array}{l}\text { Chinese } \\
(153)\end{array}$ & 11.8 & 19.0 & 19.0 & 9.8 & 40.5 \\
\hline & \multicolumn{5}{|c|}{ Percentage of Respondents, aged 16-45, with relevant qualification } \\
\hline $\begin{array}{l}\text { White } \\
(58,268)\end{array}$ & 17.9 & 30.0 & 20.0 & 10.4 & 21.8 \\
\hline $\begin{array}{l}\text { Indian } \\
(262)\end{array}$ & 26.3 & 10.7 & 16.0 & 8.0 & 38.9 \\
\hline $\begin{array}{l}\text { Pakistani } \\
(859)\end{array}$ & 28.6 & 16.1 & 17.6 & 7.9 & 29.8 \\
\hline $\begin{array}{l}\text { Chinese } \\
(117)\end{array}$ & 8.6 & 21.4 & 24.8 & 11.1 & 34.2 \\
\hline & \multicolumn{5}{|c|}{ Percentage of Respondents, aged 16-30, with relevant qualification } \\
\hline $\begin{array}{l}\text { White } \\
(21,712)\end{array}$ & 10.7 & 30.2 & 27.2 & 12.3 & 19.7 \\
\hline $\begin{array}{l}\text { Indian } \\
(129)\end{array}$ & 13.2 & 10.1 & 26.4 & 10.1 & 40.3 \\
\hline $\begin{array}{l}\text { Pakistani } \\
(407)\end{array}$ & 17.2 & 16.7 & 27.3 & 8.4 & 30.5 \\
\hline $\begin{array}{l}\text { Chinese } \\
(56)\end{array}$ & 7.1 & 25.0 & 32.1 & 16.1 & 19.6 \\
\hline
\end{tabular}

See Notes to Table 1

Source: 2001 UK Census, Sample of Anonymised Records 
Table 7

Occupation and Level of Highest Qualification in UK Regions

\begin{tabular}{|c|c|c|c|c|c|}
\hline & \multicolumn{5}{|c|}{$\begin{array}{l}\text { Percentage of persons with relevant qualification in occupational } \\
\text { class }\end{array}$} \\
\hline & $\begin{array}{c}\text { No } \\
\text { Qualifications }\end{array}$ & Level 1 & Level 2 & Level 3 & Level 4 \\
\hline \multicolumn{6}{|l|}{$\begin{array}{l}\text { North \& } \\
\text { Yorkshire }\end{array}$} \\
\hline $\begin{array}{l}\text { Managerial, } \\
\text { Professional, } \\
\text { Technical }\end{array}$ & 11.8 & 21.5 & 29.2 & 33.3 & 77.1 \\
\hline $\begin{array}{l}\text { Skilled } \\
\text { manual, non- } \\
\text { manual }\end{array}$ & 59.3 & 63.3 & 60.5 & 58.6 & 20.4 \\
\hline $\begin{array}{l}\text { Elementary } \\
\text { workers }\end{array}$ & 28.9 & 15.1 & 10.3 & 8.2 & 2.5 \\
\hline \multicolumn{6}{|l|}{$\begin{array}{l}\text { East and } \\
\text { West } \\
\text { Midlands }\end{array}$} \\
\hline $\begin{array}{l}\text { Managerial, } \\
\text { Professional, } \\
\text { Technical }\end{array}$ & 12.1 & 23.0 & 32.1 & 35.7 & 78.1 \\
\hline $\begin{array}{l}\text { Skilled } \\
\text { manual, non- } \\
\text { manual }\end{array}$ & 60.5 & 62.0 & 58.3 & 56.1 & 19.5 \\
\hline $\begin{array}{l}\text { Elementary } \\
\text { workers }\end{array}$ & 27.5 & 15.0 & 9.7 & 8.2 & 2.5 \\
\hline \multicolumn{6}{|l|}{$\begin{array}{l}\text { East, South- } \\
\text { East, South- } \\
\text { West }\end{array}$} \\
\hline $\begin{array}{l}\text { Managerial, } \\
\text { Professional, } \\
\text { Technical }\end{array}$ & 15.0 & 26.4 & 36.3 & 42.5 & 78.7 \\
\hline $\begin{array}{l}\text { Skilled } \\
\text { manual, non- } \\
\text { manual }\end{array}$ & 59.0 & 60.6 & 55.7 & 51.3 & 19.2 \\
\hline $\begin{array}{l}\text { Elementary } \\
\text { workers }\end{array}$ & 26.0 & 13.0 & 8.0 & 6.2 & 2.1 \\
\hline \multicolumn{6}{|l|}{$\begin{array}{l}\text { London, } \\
\text { Inner \& } \\
\text { Outer }\end{array}$} \\
\hline $\begin{array}{l}\text { Managerial, } \\
\text { Professional, } \\
\text { Technical }\end{array}$ & 15.8 & 27.4 & 36.0 & 42.5 & 77.7 \\
\hline $\begin{array}{l}\text { Skilled } \\
\text { manual, non- } \\
\text { manual }\end{array}$ & 59.0 & 60.2 & 56.0 & 50.9 & 19.8 \\
\hline $\begin{array}{l}\text { Elementary } \\
\text { workers }\end{array}$ & 25.2 & 12.3 & 8.0 & 6.5 & 2.4 \\
\hline
\end{tabular}




\begin{tabular}{|c|c|c|c|c|c|}
\hline & $\begin{array}{c}\text { No } \\
\text { Qualifications }\end{array}$ & Level 1 & Level 2 & Level 3 & Level 4 \\
\hline \multicolumn{6}{|l|}{ Scotland } \\
\hline $\begin{array}{l}\text { Managerial, } \\
\text { Professional, } \\
\text { Technical }\end{array}$ & 12.3 & 18.0 & 27.6 & 41.4 & 76.7 \\
\hline $\begin{array}{l}\text { Skilled } \\
\text { manual, non- } \\
\text { manual }\end{array}$ & 59.6 & 66.5 & 63.3 & 52.6 & 21.0 \\
\hline $\begin{array}{l}\text { Elementary } \\
\text { workers }\end{array}$ & 28.1 & 15.5 & 9.1 & 6.0 & 2.4 \\
\hline \multicolumn{6}{|l|}{ Wales } \\
\hline $\begin{array}{l}\text { Managerial, } \\
\text { Professional, } \\
\text { Technical }\end{array}$ & 12.0 & 20.7 & 28.1 & 31.7 & 77.0 \\
\hline $\begin{array}{l}\text { Skilled } \\
\text { manual, non- } \\
\text { manual }\end{array}$ & 59.6 & 63.9 & 61.9 & 59.4 & 20.6 \\
\hline $\begin{array}{l}\text { Elementary } \\
\text { workers }\end{array}$ & 28.4 & 15.4 & 10.1 & 8.9 & 2.4 \\
\hline \multicolumn{6}{|l|}{$\begin{array}{l}\text { Northern } \\
\text { Ireland }\end{array}$} \\
\hline $\begin{array}{l}\text { Managerial, } \\
\text { Professional, } \\
\text { Technical }\end{array}$ & 11.9 & 18.0 & 28.0 & 29.6 & 73.0 \\
\hline $\begin{array}{l}\text { Skilled } \\
\text { manual, non- } \\
\text { manual }\end{array}$ & 62.8 & 67.9 & 63.8 & 63.9 & 24.5 \\
\hline $\begin{array}{l}\text { Elementary } \\
\text { workers }\end{array}$ & 25.3 & 14.1 & 8.1 & 6.5 & 2.5 \\
\hline \multicolumn{6}{|l|}{$\begin{array}{l}\text { England, } \\
\text { Wales, and } \\
\text { Northern } \\
\text { Ireland }\end{array}$} \\
\hline $\begin{array}{l}\text { Managerial, } \\
\text { Professional, } \\
\text { Technical }\end{array}$ & 13.2 & 24.0 & 33.1 & 38.2 & 50.0 \\
\hline $\begin{array}{l}\text { Skilled } \\
\text { manual, } \\
\text { non-manual }\end{array}$ & 59.6 & 62.0 & 58.0 & 54.6 & 9.6 \\
\hline $\begin{array}{l}\text { Elementary } \\
\text { workers }\end{array}$ & 27.2 & 14.0 & 9.0 & 7.2 & 4.4 \\
\hline
\end{tabular}

Source: 2001 UK Census, Sample of Anonymised Records 
Table 8

Unemployment and Permanently Sick or Disabled and Level of Highest Qualification in UK Regions, Non-students Aged 16-65

\begin{tabular}{|c|c|c|c|c|c|}
\hline & \multicolumn{5}{|c|}{ Percentage of persons in economic status with relevant qualification } \\
\hline & $\begin{array}{c}\text { No } \\
\text { Qualifications }\end{array}$ & Level 1 & Level 2 & Level 3 & Level 4 \\
\hline \multicolumn{6}{|l|}{$\begin{array}{l}\text { North \& } \\
\text { Yorkshire }\end{array}$} \\
\hline Unemployed & 36.5 & 21.9 & 20.9 & 8.6 & 12.1 \\
\hline $\begin{array}{l}\text { Permanently } \\
\text { sick or } \\
\text { disabled }\end{array}$ & 68.1 & 12.7 & 9.7 & 2.6 & 6.9 \\
\hline \multicolumn{6}{|c|}{$\begin{array}{l}\text { East and West } \\
\text { Midlands }\end{array}$} \\
\hline Unemployed & 37.1 & 22.5 & 20.1 & 7.8 & 12.5 \\
\hline $\begin{array}{l}\text { Permanently } \\
\text { sick or } \\
\text { disabled } \\
\end{array}$ & 68.8 & 11.9 & 9.3 & 2.6 & 7.5 \\
\hline \multicolumn{6}{|l|}{$\begin{array}{l}\text { East, South- } \\
\text { East, South- } \\
\text { West }\end{array}$} \\
\hline Unemployed & 26.9 & 22.5 & 22.8 & 10.6 & 17.2 \\
\hline $\begin{array}{l}\text { Permanently } \\
\text { sick or } \\
\text { disabled }\end{array}$ & 60.2 & 14.7 & 12.0 & 3.7 & 9.4 \\
\hline \multicolumn{6}{|c|}{$\begin{array}{l}\text { London, Inner } \\
\text { \& Outer }\end{array}$} \\
\hline Unemployed & 26.3 & 16.4 & 19.6 & 11.9 & 25.8 \\
\hline $\begin{array}{l}\text { Permanently } \\
\text { sick or } \\
\text { disabled }\end{array}$ & 58.1 & 13.2 & 11.4 & 4.7 & 12.5 \\
\hline \multicolumn{6}{|l|}{ Scotland } \\
\hline Unemployed & 34.5 & 32.2 & 14.0 & 7.3 & 12.0 \\
\hline $\begin{array}{l}\text { Permanently } \\
\text { sick or } \\
\text { disabled }\end{array}$ & 65.2 & 17.5 & 7.5 & 2.7 & 7.1 \\
\hline \multicolumn{6}{|l|}{ Wales } \\
\hline Unemployed & 32.0 & 22.0 & 22.5 & 8.8 & 14.7 \\
\hline $\begin{array}{l}\text { Permanently } \\
\text { sick or } \\
\text { disabled } \\
\end{array}$ & 66.5 & 12.3 & 10.9 & 2.5 & 7.8 \\
\hline \multicolumn{6}{|l|}{$\begin{array}{l}\text { Northern } \\
\text { Ireland }\end{array}$} \\
\hline Unemployed & 49.5 & 19.7 & 13.6 & 7.7 & 9.6 \\
\hline $\begin{array}{l}\text { Permanently } \\
\text { sick or } \\
\text { disabled }\end{array}$ & 75.1 & 10.8 & 6.4 & 3.2 & 4.5 \\
\hline \multicolumn{6}{|l|}{$\begin{array}{l}\text { England, } \\
\text { Wales, and } \\
\text { Northern } \\
\text { Ireland }\end{array}$} \\
\hline Unemployed & 32.6 & 21.1 & 20.8 & 9.5 & 16.0 \\
\hline $\begin{array}{l}\text { Permanently } \\
\text { sick or } \\
\text { disabled }\end{array}$ & 65.5 & 12.9 & 10.3 & 3.1 & 8.1 \\
\hline
\end{tabular}

Source: 2001 UK Census, Sample of Anonymised Records 
Table 9

Unemployment Rates and Disability Rates by Level of Highest Qualification in UK Regions

\begin{tabular}{|c|c|c|c|c|c|c|}
\hline & \multicolumn{6}{|c|}{$\begin{array}{l}\text { Percentage of persons with relevant qualification in the labour } \\
\text { force who are unemployed or permanently sick/disabled }\end{array}$} \\
\hline & $\begin{array}{c}\text { No } \\
\text { Qualifications }\end{array}$ & Level 1 & Level 2 & Level 3 & Level 4 & $\begin{array}{c}\text { All } \\
\text { respondents }\end{array}$ \\
\hline \multicolumn{7}{|l|}{$\begin{array}{l}\text { North \& } \\
\text { Yorkshire }\end{array}$} \\
\hline $\begin{array}{l}\text { Unemployment } \\
\text { Rate }\end{array}$ & 9.5 & 5.7 & 5.4 & 5.3 & 3.1 & 5.9 \\
\hline $\begin{array}{l}\text { Permanently } \\
\text { sick/disabled } \\
\text { rate }\end{array}$ & 21.0 & 5.2 & 4.1 & 2.8 & 3.0 & 8.8 \\
\hline \multicolumn{7}{|l|}{$\begin{array}{l}\text { East and West } \\
\text { Midlands }\end{array}$} \\
\hline $\begin{array}{l}\text { Unemployment } \\
\text { Rate }\end{array}$ & 8.2 & 5.3 & 4.8 & 4.6 & 3.0 & 5.3 \\
\hline $\begin{array}{l}\text { Permanently } \\
\text { sick/disabled } \\
\text { rate }\end{array}$ & 15.7 & 3.6 & 2.9 & 2.1 & 2.4 & 6.6 \\
\hline \multicolumn{7}{|l|}{$\begin{array}{l}\text { East, South- } \\
\text { East, South- } \\
\text { West }\end{array}$} \\
\hline $\begin{array}{l}\text { Unemployment } \\
\text { Rate }\end{array}$ & 5.3 & 3.6 & 3.4 & 3.7 & 2.4 & 3.6 \\
\hline $\begin{array}{l}\text { Permanently } \\
\text { sick/disabled } \\
\text { rate }\end{array}$ & 12.6 & 3.0 & 2.3 & 1.7 & 1.7 & 4.4 \\
\hline \multicolumn{7}{|l|}{$\begin{array}{l}\text { London, Inner } \\
\text { \& Outer }\end{array}$} \\
\hline $\begin{array}{l}\text { Unemployment } \\
\text { Rate }\end{array}$ & 11.6 & 7.4 & 7.1 & 7.5 & 4.1 & 6.6 \\
\hline $\begin{array}{l}\text { Permanently } \\
\text { sick/disabled } \\
\text { rate }\end{array}$ & 15.9 & 4.7 & 3.4 & 2.5 & 1.8 & 5.3 \\
\hline \multicolumn{7}{|l|}{ Scotland } \\
\hline $\begin{array}{l}\text { Unemployment } \\
\text { Rate }\end{array}$ & 9.3 & 7.3 & 4.9 & 4.7 & 3.0 & 6.0 \\
\hline $\begin{array}{l}\text { Permanently } \\
\text { sick/disabled } \\
\text { rate }\end{array}$ & 21.4 & 6.1 & 4.3 & 2.9 & 2.9 & 9.1 \\
\hline \multicolumn{7}{|l|}{ Wales } \\
\hline $\begin{array}{l}\text { Unemployment } \\
\text { Rate }\end{array}$ & 8.3 & 6.3 & 5.3 & 5.7 & 3.5 & 5.8 \\
\hline $\begin{array}{l}\text { Permanently } \\
\text { sick/disabled } \\
\text { rate }\end{array}$ & 25.1 & 7.0 & 5.3 & 3.6 & 4.1 & 11.0 \\
\hline
\end{tabular}




\begin{tabular}{|l|c|c|c|c|c|c|}
\hline $\begin{array}{l}\text { Northern } \\
\text { Ireland }\end{array}$ & 11.5 & 6.6 & 5.1 & 4.8 & 2.9 & 6.7 \\
\hline $\begin{array}{l}\text { Unemployment } \\
\text { Rate }\end{array}$ & 23.0 & 6.3 & 4.4 & 3.7 & 2.7 & 11.1 \\
\hline $\begin{array}{l}\text { Permanently } \\
\text { sick/disabled } \\
\text { rate }\end{array}$ & & 5.1 & 4.7 & 4.9 & 3.1 & 5.1 \\
\hline $\begin{array}{l}\text { England, } \\
\text { Wales and } \\
\text { Northern } \\
\text { Ireland }\end{array}$ & 15.7 & 3.6 & 2.9 & 2.1 & 2.4 & 6.6 \\
\hline $\begin{array}{l}\text { Unemployment } \\
\text { Rate }\end{array}$ & & & & & & \\
\hline $\begin{array}{l}\text { Permanently } \\
\text { sick/disabled } \\
\text { rate }\end{array}$ & 8.1 & & & & & \\
\hline
\end{tabular}

Unemployment rate: proportion of the labour force that is unemployed and available to start work within 2 weeks.

Permanently sick/disabled rate: proportion of the non-student, non-retired population which is permanently sick or disabled.

Source: 2001 UK Census, Sample of Anonymised Records 
Table 10

Ordered Logit Estimates of Employment in Occupational Class, by UK

Region

\begin{tabular}{|c|c|c|c|c|c|c|c|}
\hline & $\begin{array}{l}\text { North, } \\
\text { North } \\
\text { West and } \\
\text { Yorkshire }\end{array}$ & Midlands & $\begin{array}{l}\text { East, } \\
\text { South } \\
\text { East, and } \\
\text { South } \\
\text { West }\end{array}$ & London & Wales & Scotland & $\begin{array}{l}\text { Northern } \\
\text { Ireland }\end{array}$ \\
\hline \multirow[t]{2}{*}{ Female } & $0.202^{* \star *}$ & $0.291^{* * *}$ & $0.360^{* * *}$ & $0.255^{* * *}$ & $0.178^{* * *}$ & $0.129 * * *$ & $0.071^{* *}$ \\
\hline & $(19.62)$ & $(23.60)$ & $(41.61)$ & $(17.96)$ & $(7.63)$ & $(7.97)$ & $(2.14)$ \\
\hline \multirow[t]{2}{*}{ Level 1} & $-0.961^{* * *}$ & $-0.929 * \star \star$ & $-0.979 * \star *$ & $-0.866^{* * *}$ & $-0.897^{* * *}$ & $-0.790^{\star \star \star}$ & $-0.809 * * *$ \\
\hline & $(6 \odot .02)$ & $(49.42)$ & $(69.92)$ & $(34.03)$ & $(24.51)$ & $(32.85)$ & $(16.08)$ \\
\hline \multirow[t]{2}{*}{ Level 2} & $-1.440^{* * \star}$ & $-1.449 * \star \star$ & $-1.527^{\star \star *}$ & $-1.353^{* \star \star}$ & $-1.348^{* * *}$ & $-1.378^{\star \star \star}$ & $-1.368^{* \star \star}$ \\
\hline & $(88.49)$ & $(75.62)$ & $(108.94)$ & $(54.91)$ & $(38.04)$ & $(51.14)$ & $(26.53)$ \\
\hline \multirow[t]{2}{*}{ Level 3} & $-1.834^{* * *}$ & $-1.826^{* \star \star}$ & $-1.953^{* \star *}$ & $-1.774^{* * *}$ & $-1.775^{* * *}$ & $-1.947^{* \star *}$ & $-1.615^{* * *}$ \\
\hline & $(88.73)$ & $(73.64)$ & $(112.00)$ & $(62.37)$ & $(37.58)$ & $(60.72)$ & $(26.21)$ \\
\hline \multirow{2}{*}{ Level 4} & $-3.507^{* * *}$ & $-3.473^{* * *}$ & $-3.380^{* * *}$ & $-3.269^{* * *}$ & $-3.479^{* * *}$ & $-3.433^{* * *}$ & $-3.338^{* * *}$ \\
\hline & $(190.54)$ & $(157.88)$ & $(214.66)$ & $(133.29)$ & $(85.47)$ & $(122.54)$ & $(60.02)$ \\
\hline \multirow[t]{2}{*}{$\begin{array}{l}30-44 \\
\text { yrs }\end{array}$} & $-0.475^{\star \star *}$ & $-0.513^{* \star *}$ & $-0.534^{* * *}$ & $-0.440^{* \star *}$ & $-0.554^{* * *}$ & $-0.530^{* \star \star}$ & $-0.599^{* * *}$ \\
\hline & $(35.73)$ & $(31.76)$ & $(47.28)$ & $(25.49)$ & $(18.22)$ & $(25.43)$ & $(14.55)$ \\
\hline \multirow[t]{2}{*}{$\begin{array}{l}45-54 \\
\text { yrs }\end{array}$} & $-0.722^{* * *}$ & $-0.717^{* * *}$ & $-0.767^{* * *}$ & $-0.459^{* * *}$ & $-0.807^{* * *}$ & $-0.683^{* * *}$ & $-0.934^{* * *}$ \\
\hline & $(45.69)$ & $(37.77)$ & $(58.52)$ & $(21.13)$ & $(22.99)$ & $(28.16)$ & $(18.32)$ \\
\hline \multirow[t]{2}{*}{$\begin{array}{l}55-64 \\
\text { yrs }\end{array}$} & $-0.693^{* * *}$ & $-0.668^{* \star *}$ & $-0.701^{* \star *}$ & $-0.352^{* \star *}$ & $-0.768^{* * *}$ & $-0.631^{* \star *}$ & $-0.913^{\star * *}$ \\
\hline & $(34.48)$ & $(28.83)$ & $(43.85)$ & $(12.62)$ & $(17.48)$ & $(20.61)$ & $(14.28)$ \\
\hline \multirow[t]{2}{*}{$\begin{array}{l}\text { Irish } \\
\text { born }\end{array}$} & 0.075 & $0.181^{* *}$ & 0.049 & $0.200^{* * *}$ & 0.139 & $-0.309^{*}$ & $-0.301^{* * *}$ \\
\hline & $(0.98)$ & $(2.38)$ & $(0.92)$ & $(4.07)$ & $(0.74)$ & $(2.36)$ & $(2.62)$ \\
\hline \multirow[t]{2}{*}{$\begin{array}{l}\text { European } \\
\text { born }\end{array}$} & 0.030 & $0.106^{*}$ & 0.043 & $0.343^{* * *}$ & 0.003 & -0.140 * & 0.018 \\
\hline & $(0.57)$ & $(1.73)$ & $(1.40)$ & $(10.43)$ & $(0.03)$ & $(1.76)$ & $(0.08)$ \\
\hline \multirow[t]{2}{*}{$\begin{array}{l}\text { Non- } \\
\text { European } \\
\text { born }\end{array}$} & $-0.162^{* * *}$ & -0.002 & $-0.075^{* * *}$ & $0.185^{* * *}$ & $-0.194^{*}$ & $-0.313^{* * *}$ & -0.331 \\
\hline & $(3.94)$ & $(0.05)$ & $(2.94)$ & $(8.31)$ & $(1.71)$ & $(4.77)$ & $(1.58)$ \\
\hline \multirow[t]{2}{*}{ Mixed } & $0.136^{*}$ & -0.124 & -0.003 & $0.274^{* * *}$ & -0.022 & & \\
\hline & $(1.87)$ & $(1.55)$ & $(0.05)$ & $(5.27)$ & $(0.12)$ & & \\
\hline \multirow[t]{2}{*}{ Asian } & -0.020 & $0.179^{* * *}$ & $0.219 * * *$ & $0.413^{* * *}$ & -0.251 & & \\
\hline & $(0.46)$ & $(4.65)$ & $(5.69)$ & $(15.14)$ & $(1.46)$ & & \\
\hline \multirow[t]{2}{*}{ Black } & $0.311^{* * *}$ & $0.205^{* * *}$ & $0.370 * * *$ & $0.723^{* * *}$ & 0.241 & & \\
\hline & $(4.28)$ & $(3.77)$ & $(7.08)$ & $(27.68)$ & $(0.91)$ & & \\
\hline \multirow[t]{2}{*}{ Chinese } & -0.021 & 0.003 & 0.069 & $0.267^{* * *}$ & -0.213 & & \\
\hline & $(0.24)$ & $(0.03)$ & $(1.11)$ & $(5.47)$ & $(0.99)$ & & \\
\hline \multirow[t]{2}{*}{ Catholic } & & & & & & & 0.006 \\
\hline & & & & & & & $(0.17)$ \\
\hline \multirow[t]{2}{*}{ Indian } & & & & & & 0.171 & \\
\hline & & & & & & $(1.09)$ & \\
\hline \multirow[t]{2}{*}{ Pakistan } & & & & & & $-0.468^{* * *}$ & \\
\hline & & & & & & $(4.66)$ & \\
\hline \multirow[t]{2}{*}{ other } & & & & & & $0.387^{* * *}$ & \\
\hline & & & & & & $(2.64)$ & \\
\hline $\mathrm{N}$ & 165922 & 114937 & 235552 & 93607 & 32498 & 68536 & 16875 \\
\hline
\end{tabular}




\section{Notes to Table 10:}

The equation was estimated over all those persons in employment (employees or selfemployed).

Dependent variable: $=1$, if person is employed in a professional, managerial, or technical occupation; $=2$, if employed in a skilled manual/non-manual occupation; $=3$ if employed in an elementary occupation.

Levels of Qualification are defined under Table 1: residual is "no qualifications". Residual age category is 19-29 years.

Residual birthplace is "UK born".

Residual ethnicity in England and Wales, and in Scotland is "White".

Residual religion (Northern Ireland only) is "Protestant".

Absolute value of $\mathrm{z}$ statistics in parentheses;

* significant at $10 \% ; * *$ significant at $5 \% ; * * *$ significant at $1 \%$ 
Table 11

Marginal Probabilities of Being Employed in Professional, Managerial, Technical Occupations, by UK Region

\begin{tabular}{|c|c|c|c|c|c|c|c|}
\hline & $\begin{array}{l}\text { North, } \\
\text { North } \\
\text { West and } \\
\text { Yorkshire }\end{array}$ & Midlands & $\begin{array}{l}\text { East, } \\
\text { South } \\
\text { East, and } \\
\text { South } \\
\text { West }\end{array}$ & London & Wales & Scotland & $\begin{array}{l}\text { Northern } \\
\text { Ireland }\end{array}$ \\
\hline \multirow[t]{2}{*}{ Female } & $-0.046 * * *$ & $-0.067 * * *$ & $-0.088^{* * *}$ & $-0.063^{* * *}$ & $-0.040 * * *$ & $-0.029 * * *$ & $-0.015^{\star \star}$ \\
\hline & $(19.6)$ & $(23.6)$ & $(41.6)$ & $(18.0)$ & $(7.6)$ & $(8.0)$ & $(2.1)$ \\
\hline \multirow[t]{2}{*}{ Level 1} & $0.228 * \star \star$ & $0.223 * \star \star *$ & $0.240 * \star \star$ & $0.203 * \star *$ & $0.213 * * *$ & $0.186 * * *$ & $0.183^{\star \star *}$ \\
\hline & $(59.6)$ & $(49.3)$ & $(72.6)$ & $(37.2)$ & $(24.2)$ & $(32.4)$ & $(15.4)$ \\
\hline \multirow[t]{2}{*}{ Level 2} & $0.341^{* \star *}$ & $0.345^{* \star *}$ & $0.363^{* \star *}$ & $0.304 * * *$ & $0.318 * * *$ & $0.329 * * \star$ & $0.317^{\star * *}$ \\
\hline & $(92.54)$ & $(80.1)$ & $(121.7)$ & $(64.4)$ & $(39.2)$ & $(53.3)$ & $(26.4)$ \\
\hline \multirow[t]{2}{*}{ Level 3} & $0.428 * \star \star$ & $0.425 * \star \star$ & $0.432^{* \star \star}$ & $0.361^{* \star *}$ & $0.416 * \star \star$ & $0.450 * \star *$ & $0.379 * \star \star$ \\
\hline & $(105.2)$ & $(88.9)$ & $(149.9)$ & $(86.0)$ & $(43.9)$ & $(74.1)$ & $(27.4)$ \\
\hline \multirow[t]{2}{*}{ Level 4} & $0.697 * \star \star$ & $0.689 * \star \star *$ & $0.664^{* \star \star}$ & $0.661^{* \star *}$ & 0.696 *** & $0.692^{* \star *}$ & $0.682^{\star \star \star}$ \\
\hline & $(327.1)$ & $(272.9)$ & $(362.4)$ & $(200.6)$ & $(143.6)$ & $(201.8)$ & $(93.8)$ \\
\hline \multirow[t]{2}{*}{$\begin{array}{l}30-44 \\
\text { yrs }\end{array}$} & $0.108^{* * *}$ & $0.119 * \star *$ & $0.131^{* \star *}$ & $0.109 * * *$ & $0.127^{* \star *}$ & $0.121^{* \star *}$ & $0.127^{* \star *}$ \\
\hline & 35.63 & $(31.7)$ & $(47.5)$ & $(25.8)$ & $(18.2)$ & $(25.3)$ & $(14.4)$ \\
\hline \multirow[t]{2}{*}{$\begin{array}{l}45-54 \\
\text { yrs }\end{array}$} & 0.171 & $0.171^{* \star *}$ & $0.189^{* * *}$ & $0.112^{* * *}$ & $0.190^{* * *}$ & $0.161^{* \star *}$ & $0.212^{\star \star \star}$ \\
\hline & $(44.7)$ & $(37.1)$ & $(59.4)$ & $(21.7)$ & $(22.6)$ & $(27.5)$ & $(17.5)$ \\
\hline \multirow[t]{2}{*}{$\begin{array}{l}55-64 \\
\text { yrs }\end{array}$} & $0.166^{* * *}$ & $0.161^{* * *}$ & $0.173^{* * *}$ & $0.086^{* * *}$ & $0.184^{* * *}$ & $0.151^{* * *}$ & $0.212^{* *}$ \\
\hline & $(33.5)$ & $(28.2)$ & $(44.6)$ & $(10.5)$ & $(17.0)$ & $(20.0)$ & $(13.6)$ \\
\hline \multirow[t]{2}{*}{$\begin{array}{l}\text { Irish } \\
\text { born }\end{array}$} & -0.017 & $-0.041^{*} *$ & -0.011 & $-0.50 * \star \star$ & -0.031 & $0.073^{*} *$ & $0.067^{*} *$ \\
\hline & $(0.99)$ & $(2.5)$ & $(0.92)$ & $(4.1)$ & $(0.76)$ & $(2.3)$ & $(2.5)$ \\
\hline \multirow[t]{2}{*}{$\begin{array}{l}\text { European } \\
\text { born }\end{array}$} & -0.007 & -0.024 & -0.011 & $-0.085^{* \star *}$ & -0.001 & 0.032 & -0.004 \\
\hline & $(0.58)$ & $(1.8)$ & $(1.41)$ & $(10.5)$ & $(0.03)$ & $(1.7)$ & $(0.08)$ \\
\hline \multirow[t]{2}{*}{$\begin{array}{l}\text { Non- } \\
\text { European } \\
\text { born }\end{array}$} & $0.038^{* *}$ & 0.000 & 0.019 ** & $-0.046^{* * *}$ & 0.045 & $0.073^{* * *}$ & 0.074 \\
\hline & $(3.9)$ & $(0.1)$ & $(2.9)$ & $(8.3)$ & $(1.7)$ & $(4.6)$ & $(1.5)$ \\
\hline \multirow[t]{2}{*}{ Mixed } & $-0.030 * *$ & 0.029 & 0.001 & $-0.068 * \star \star$ & 0.005 & & \\
\hline & $(2.0)$ & $(1.5)$ & $(0.05)$ & $(5.3)$ & $(0.12)$ & & \\
\hline \multirow[t]{2}{*}{ Asian } & 0.005 & $-0.040 * * *$ & -0.053 & $-0.103^{* * *}$ & 0.059 & & \\
\hline & $(0.46)$ & $(4.8)$ & $(5.8)$ & $(15.3)$ & $(1.4)$ & & \\
\hline \multirow[t]{2}{*}{ Black } & $-0.067 * *$ & $-0.046 * * *$ & -0.087 & $-0.178 * \star *$ & -0.052 & & \\
\hline & $(4.55)$ & $(3.9)$ & $(7.4)$ & $(29.0)$ & $(0.96)$ & & \\
\hline \multirow[t]{2}{*}{ Chinese } & 0.004 & -0.001 & -0.017 & $-0.067 * \star *$ & 0.050 & & \\
\hline & $(0.24)$ & $(0.03)$ & $(1.12)$ & $(5.5)$ & $(0.96)$ & & \\
\hline \multirow[t]{2}{*}{ Catholic } & & & & & & & -0.001 \\
\hline & & & & & & & $(0.17)$ \\
\hline \multirow[t]{2}{*}{ Indian } & & & & & & -0.038 & \\
\hline & & & & & & $(1.1)$ & \\
\hline \multirow[t]{2}{*}{ Pakistan } & & & & & & $0.112^{* * *}$ & \\
\hline & & & & & & $(4.5)$ & \\
\hline \multirow[t]{2}{*}{ other } & & & & & & $-0.082^{* *}$ & \\
\hline & & & & & & $(2.9)$ & \\
\hline $\mathrm{N}$ & 165922 & 114937 & 235552 & 93607 & 32498 & 68536 & 16875 \\
\hline
\end{tabular}


Table 12

Logit Estimates of Unemployment Employment Equations by UK Region

\begin{tabular}{|c|c|c|c|c|c|c|c|}
\hline & $\begin{array}{l}\text { North, North } \\
\text { West and } \\
\text { Yorkshire }\end{array}$ & Midlands & $\begin{array}{l}\text { East, South } \\
\text { East, and } \\
\text { South West }\end{array}$ & London & Wales & Scotland & $\begin{array}{l}\text { Northern } \\
\text { Ireland }\end{array}$ \\
\hline \multirow[t]{2}{*}{ Female } & $-0.480^{* \star \star}$ & $-0.317^{* * *}$ & $-0.199 * \star \star$ & $-0.323^{* * *}$ & $-0.332 * * *$ & $-0.460 * * *$ & $-0.337^{* * *}$ \\
\hline & $(22.23)$ & $(11.87)$ & $(8.93)$ & $(12.16)$ & $(6.92)$ & $(14.06)$ & $(5.20)$ \\
\hline \multirow[t]{2}{*}{ Level 1} & $-0.774^{\star \star \star}$ & $-0.651^{* \star \star}$ & $-0.539 * * *$ & $-0.655^{\star \star \star}$ & $-0.513^{* \star *}$ & $-0.542^{* \star \star}$ & $-0.830^{* \star *}$ \\
\hline & $(26.43)$ & $(17.82)$ & $(16.37)$ & $(15.36)$ & $(7.67)$ & $(13.14)$ & $(9.79)$ \\
\hline \multirow[t]{2}{*}{ Level 2} & $-0.902^{* * *}$ & $-0.812^{* \star *}$ & $-0.679 * * *$ & $-0.759 * * \star$ & $-0.725^{* * *}$ & $-1.027^{* * *}$ & $-1.113^{* * *}$ \\
\hline & $(30.09)$ & $(21.38)$ & $(20.58)$ & $(18.64)$ & $(10.90)$ & $(19.75)$ & $(11.56)$ \\
\hline \multirow[t]{2}{*}{ Level 3} & $-1.088^{* \star \star}$ & $-1.051^{* \star \star}$ & $-0.721^{* \star \star}$ & $-0.786^{\star \star \star}$ & $-0.857^{* \star \star}$ & $-1.074^{* \star \star}$ & $-1.465^{\star \star \star}$ \\
\hline & $(26.63)$ & $(19.75)$ & $(17.26)$ & $(16.56)$ & $(9.29)$ & $(16.42)$ & $(11.53)$ \\
\hline \multirow[t]{2}{*}{ Level 4} & $-1.431^{* \star \star}$ & $-1.320 * * \star$ & $-1.025^{* * *}$ & $-1.365^{* * *}$ & $-1.101^{* * *}$ & $-1 \cdot 413^{* * *}$ & $-1.820^{* * *}$ \\
\hline & $(41.26)$ & $(30.60)$ & $(29.30)$ & $(36.22)$ & $(14.79)$ & $(26.56)$ & $(16.18)$ \\
\hline \multirow[t]{2}{*}{$\begin{array}{l}30-44 \\
\text { yrs }\end{array}$} & $-0.751^{* \star \star *}$ & $-0.704 * \star \star *$ & $-0.664 * \star \star *$ & $-0.452 * \star \star *$ & $-0.796 * \star *$ & $-0.678 * \star *$ & $-0.690 * * *$ \\
\hline & $(30.88)$ & $(22.66)$ & $(25.20)$ & $(14.97)$ & $(14.54)$ & $(18.13)$ & $(9.31)$ \\
\hline \multirow[t]{2}{*}{$\begin{array}{l}45-54 \\
y r s\end{array}$} & $-1.165^{* \star *}$ & $-1.021^{* \star *}$ & $-0.925^{* \star *}$ & $-0.717^{* \star *}$ & $-1.188^{* * *}$ & $-1.038^{* * *}$ & $-0.977^{* * *}$ \\
\hline & $(35.80)$ & $(25.37)$ & $(27.73)$ & $(17.29)$ & $(16.52)$ & $(21.55)$ & $(10.26)$ \\
\hline \multirow[t]{2}{*}{$\begin{array}{l}55-64 \\
\text { yrs }\end{array}$} & $-1.227^{* \star *}$ & $-1 \cdot 157^{* \star *}$ & $-0.873^{* * *}$ & $-0.846^{* \star *}$ & $-1.201^{* \star *}$ & $-1.190 * * *$ & $-1.200 * * *$ \\
\hline & $(29.83)$ & $(23.00)$ & $(21.85)$ & $(15.48)$ & $(13.14)$ & $(19.10)$ & $(9.77)$ \\
\hline \multirow[t]{2}{*}{$\begin{array}{l}\text { Irish } \\
\text { born }\end{array}$} & 0.204 & $0.516^{* * *}$ & $0.434^{* * *}$ & $0.243^{* *}$ & 0.386 & -0.184 & 0.231 \\
\hline & $(1.39)$ & $(3.75)$ & $(3.75)$ & $(2.54)$ & $(1.16)$ & $(0.64)$ & $(1.23)$ \\
\hline \multirow[t]{2}{*}{$\begin{array}{l}\text { European } \\
\text { born }\end{array}$} & $0.274^{* * *}$ & $0.348^{* \star *}$ & $0.349 * * *$ & $0.500 * * *$ & 0.303 & $0.235^{*}$ & 0.445 \\
\hline & $(2.90)$ & $(3.04)$ & $(5.20)$ & $(8.83)$ & $(1.46)$ & $(1.77)$ & $(1.22)$ \\
\hline \multirow[t]{2}{*}{$\begin{array}{l}\text { Non- } \\
\text { European } \\
\text { born }\end{array}$} & -0.025 & -0.102 & 0.035 & $0.215^{* \star *}$ & 0.021 & -0.053 & $0.955^{* \star *}$ \\
\hline & $(0.38)$ & $(1.58)$ & $(0.59)$ & $(5.87)$ & $(0.10)$ & $(0.44)$ & $(3.25)$ \\
\hline \multirow[t]{2}{*}{ Mixed } & $0.811^{* \star *}$ & $1.099 * \star *$ & $0.649 * \star *$ & $0.867^{\star \star *}$ & $0.747^{\star * \star}$ & & \\
\hline & $(7.97)$ & $(10.70)$ & $(6.33)$ & $(11.73)$ & $(2.99)$ & & \\
\hline \multirow[t]{2}{*}{ Asian } & $0.671^{* * *}$ & $0.830^{* * *}$ & $0.642^{* * *}$ & $0.515^{* \star *}$ & 0.229 & & \\
\hline & $(10.68)$ & $(14.08)$ & $(8.72)$ & $(11.31)$ & $(0.82)$ & & \\
\hline \multirow[t]{2}{*}{ Black } & $1.057^{* * *}$ & $1.276^{\star \star \star}$ & $1.017^{* \star *}$ & $1.157^{\star \star \star}$ & 0.588 & & \\
\hline & $(10.61)$ & $(17.27)$ & $(11.41)$ & $(29.90)$ & $(1.39)$ & & \\
\hline \multirow[t]{2}{*}{ Chinese } & $0.666^{* * *}$ & $0.865 * * *$ & $0.384 * * *$ & $0.529 * * *$ & -0.469 & & \\
\hline & $(5.08)$ & $(5.40)$ & $(2.93)$ & $(6.75)$ & $(0.95)$ & & \\
\hline \multirow[t]{2}{*}{ Catholic } & & & & & & & $0.647^{* \star *}$ \\
\hline & & & & & & & $(10.40)$ \\
\hline \multirow[t]{2}{*}{ Indian } & & & & & & 0.251 & \\
\hline & & & & & & $(0.96)$ & \\
\hline \multirow[t]{2}{*}{ Pakistan } & & & & & & $0.555^{\star \star \star}$ & \\
\hline & & & & & & $(3.90)$ & \\
\hline \multirow[t]{2}{*}{ other } & & & & & & $0.863^{* * *}$ & \\
\hline & & & & & & $(4.11)$ & \\
\hline \multirow[t]{2}{*}{ Constant } & $-0.784^{\star \star \star}$ & $-1 \cdot 291^{* \star \star}$ & $-1.940 * * *$ & $-1 \cdot 371^{\star \star *}$ & $-1.096^{* \star *}$ & $-0.838^{* \star *}$ & $-1 \cdot 181^{\star \star *}$ \\
\hline & $(20.36)$ & $(26.60)$ & $(45.38)$ & $(26.63)$ & $(12.79)$ & $(13.93)$ & $(10.23)$ \\
\hline $\mathrm{N}$ & 176730 & 121810 & 246382 & 100389 & 34592 & 73340 & 18224 \\
\hline
\end{tabular}

Notes to Table 12:

The equation was estimated over all persons in the labour force i.e. employed (employees or selfemployed) or unemployed

Dependent variable: $=1$, if person is unemployed; $=0$, if employed.

Levels of Qualification are defined under Table 1: residual is "no qualifications". Residual age category is $19-29$ years.

Residual birthplace is "UK born".

Residual ethnicity in England and Wales, and in Scotland is "White".

Residual religion (Northern Ireland only) is "Protestant".

Absolute value of $\mathrm{z}$ statistics in parentheses;

* significant at $10 \% ; * *$ significant at $5 \% ; * * *$ significant at $1 \%$ 
Table 13

Marginal Probabilities of Being Unemployed, by UK Region

\begin{tabular}{|c|c|c|c|c|c|c|c|}
\hline & $\begin{array}{l}\text { North, } \\
\text { North } \\
\text { West and } \\
\text { Yorkshire }\end{array}$ & Midlands & $\begin{array}{l}\text { East, } \\
\text { South } \\
\text { East, and } \\
\text { South } \\
\text { West }\end{array}$ & London & Wales & Scotland & $\begin{array}{l}\text { Northern } \\
\text { Ireland }\end{array}$ \\
\hline \multirow[t]{2}{*}{ Female } & $-\odot .022^{* * *}$ & $-0.014^{\star * *}$ & $-0.006^{* * *}$ & $-0.017^{* * *}$ & $-0.016^{* * *}$ & $-0.022^{* * *}$ & $-0.017^{* * *}$ \\
\hline & $(22.6)$ & $(11.9)$ & $(9.0)$ & $(12.2)$ & $(7.0)$ & $(14.4)$ & $(5.2)$ \\
\hline \multirow[t]{2}{*}{ Level 1} & $-0.030^{* * *}$ & $-0.024^{* \star *}$ & $-0.015^{* * *}$ & $-0.028^{* * *}$ & $-\odot .022^{* * *}$ & $-0.023^{* * *}$ & $-0.033^{* * *}$ \\
\hline & $(31.4)$ & $(20.8)$ & $(18.8)$ & $(18.7)$ & $(8.8)$ & $(14.6)$ & $(11.9)$ \\
\hline \multirow{2}{*}{ Level 2} & $-0.034^{* * *}$ & $-0.029^{* * *}$ & $-0.018^{* * *}$ & $-0.032^{* * *}$ & $-0.030^{* * *}$ & $-0.038^{* * *}$ & $-0.041^{* * *}$ \\
\hline & $(36.5)$ & $(25.8)$ & $(24.1)$ & $(22.7)$ & $(12.8)$ & $(26.1)$ & $(15.2)$ \\
\hline \multirow[t]{2}{*}{ Level 3} & $-0.035^{* * *}$ & $-0.031^{* * *}$ & $-0.017^{* * *}$ & $-0.031^{* * *}$ & $-0.030^{* * *}$ & $-0.036^{* * *}$ & $-0.046^{* * *}$ \\
\hline & $(39.2)$ & $(29.1)$ & $(22.7)$ & $(21.8)$ & $(12.8)$ & $(24.3)$ & $(18.1)$ \\
\hline \multirow[t]{2}{*}{ Level 4} & $-0.049^{* * *}$ & $-0.043^{* \star *}$ & $-0.026^{* * *}$ & $-0.067^{* * *}$ & $-0.042^{* * *}$ & $-0.052^{* \star *}$ & $-0.062^{* * *}$ \\
\hline & $(55.6)$ & $(41.0)$ & $(36.2)$ & $(38.1)$ & $(18.8)$ & $(35.4)$ & $(23.3)$ \\
\hline \multirow[t]{2}{*}{$\begin{array}{l}30-44 \\
\text { yrs }\end{array}$} & $-0.034^{* * *}$ & $-0.029^{* * *}$ & $-0.020^{* * *}$ & $-0.023^{* * *}$ & $-0.036^{* * *}$ & $-0.031^{* * *}$ & $-0.033^{* * *}$ \\
\hline & $(31.8)$ & $(23.5)$ & $(26.3)$ & $(15.3)$ & $(15.2)$ & $(18.8)$ & $(9.7)$ \\
\hline \multirow[t]{2}{*}{$\begin{array}{l}45-54 \\
\text { yrs }\end{array}$} & $-0.042^{\star * *}$ & $-0.035^{* \star *}$ & $-0.023^{* * *}$ & $-0.031^{* * *}$ & $-0.044^{* * *}$ & $-0.040^{* \star *}$ & $-0.038^{* * *}$ \\
\hline & $(46.1)$ & $(31.9)$ & $(34.4)$ & $(21.3)$ & $(21.3)$ & $(26.9)$ & $(12.9)$ \\
\hline \multirow[t]{2}{*}{$\begin{array}{l}55-64 \\
\text { yrs }\end{array}$} & $-0.038^{* * *}$ & $-0.034^{* * *}$ & $-0.020^{* * *}$ & $-0.033^{* * *}$ & $-0.039^{* * *}$ & $-0.039^{* * *}$ & $-0.040^{* * *}$ \\
\hline & $(45.0)$ & $(33.6)$ & $(29.6)$ & $(21.3)$ & (19.7) & $(28.4)$ & $(14.5)$ \\
\hline \multirow[t]{2}{*}{$\begin{array}{l}\text { Irish } \\
\text { born }\end{array}$} & 0.010 & $0.028 * *$ & $0.017^{* *}$ & $0.014^{* *}$ & 0.022 & -0.008 & 0.013 \\
\hline & $(1.27)$ & $(3.0)$ & $(3.1)$ & $(2.3)$ & $(0.99)$ & $(0.7)$ & $(1.1)$ \\
\hline \multirow[t]{2}{*}{$\begin{array}{l}\text { European } \\
\text { born }\end{array}$} & $0.014 * *$ & 0.017 ** & $0.013^{* * *}$ & $0.032^{* * *}$ & 0.017 & 0.013 & 0.027 \\
\hline & $(2.6)$ & $(2.6)$ & $(4.5)$ & $(7.4)$ & $(1.3)$ & $(1.6)$ & $(1.0)$ \\
\hline \multirow{2}{*}{$\begin{array}{l}\text { Non- } \\
\text { European } \\
\text { born }\end{array}$} & -0.001 & -0.004 & 0.001 & $0.012^{* * *}$ & 0.001 & -0.002 & $0.072 * *$ \\
\hline & $(0.38)$ & $(1.7)$ & $(0.58)$ & $(5.6)$ & $(0.10)$ & $(0.45)$ & $(2.3)$ \\
\hline \multirow[t]{2}{*}{ Mixed } & $0.054^{* * *}$ & $0.078^{* \star *}$ & $0.027^{* * *}$ & $0.066^{* * *}$ & $0.050^{*} *$ & & \\
\hline & $(5.8)$ & $(7.1)$ & $(4.8)$ & $(8.6)$ & $(2.2)$ & & \\
\hline \multirow[t]{2}{*}{ Asian } & $0.042 * \star *$ & $0.050^{* * *}$ & $\odot .027^{* \star *}$ & $0.032 * \star *$ & 0.012 & & \\
\hline & $(8.2)$ & $(10.4)$ & $(6.7)$ & $(9.6)$ & $(0.7)$ & & \\
\hline \multirow[t]{2}{*}{ Black } & $0.079 * * *$ & $\odot .097^{* * *}$ & $0.051^{* * *}$ & $0.092^{* * *}$ & 0.037 & & \\
\hline & $(7.2)$ & $(11.1)$ & $(7.6)$ & $(21.5)$ & $(1.1)$ & & \\
\hline \multirow[t]{2}{*}{ Chinese } & $0.042^{* * *}$ & $0.055^{* *}$ & $0.014^{* *}$ & $0.034 * * *$ & -0.018 & & \\
\hline & $(3.9)$ & $(3.9)$ & $(2.5)$ & $(5.5)$ & $(1.2)$ & & \\
\hline \multirow[t]{2}{*}{ Catholic } & & & & & & & $0.033^{* * *}$ \\
\hline & & & & & & & $(10.1)$ \\
\hline \multirow[t]{2}{*}{ Indian } & & & & & & 0.014 & \\
\hline & & & & & & $(0.86)$ & \\
\hline \multirow[t]{2}{*}{ Pakistan } & & & & & & $0.034^{* *}$ & \\
\hline & & & & & & $(3.1)$ & \\
\hline \multirow[t]{2}{*}{ other } & & & & & & 0.061 & \\
\hline & & & & & & $(3.0)$ & \\
\hline $\mathrm{N}$ & 165922 & 114937 & 235552 & 93607 & 32498 & 68536 & 16875 \\
\hline
\end{tabular}

